\title{
Morphostructural Differentiation and Variability of Merino Sheep Breed Under Sustained Directional Selection
}

\author{
Diferenciación y Variabilidad Morfoestructural de Ovinos de \\ Raza Merino Sometidos a Selección Direccional Sostenida
}

\author{
R. de la Barra*; E. Latorre**; M. E. Martínez \& C. Calderón ${ }^{* *}$
}

DE LA BARRA, R.; LATORRE, E.; MARTÍNEZ, M. E. \& CALDERÓN, C. Morphostructural differentiation and variability of Merino sheep breed under sustained directional selection. Int. J. Morphol., 32(3):1069-1073, 2014.

SUMMARY In this paper, the degree of differentiation and morphostructural variability reached by the type of animal resulting from sustained directional selection, in addition to its implications for the emergence of a new sheep breed are analyzed. Twenty-five rams and 200 ewes from a sheep flock submitted to directional selection since 1987 were measured. Thirteen body measurements were taken in other to evaluate the structural morphology and sexual dimorphism. These measurements were compared with identical measures taken in Australian Merino and Marin Magellan Meat Merino sheep breeds. The intrapopulation homogeneity was assessed using the coefficients of variation of the average percentage of body measurements. It is concluded that sustained directional selection has generated the differentiation of the morphostructural format of the subject population compared to the main Merino-type breeds in the Chilean Patagonia. The population shows a similar (and in some cases lower) morphostructural variability than those found in recognized sheep breeds in Chile, so it is possible to state that this population behaves like a different animal group, with breed characteristics.

KEY WORDS: Breeding; Genetics; Morphology.

\section{INTRODUCTION}

Directional selection based on phenotypic conformation has been a widely used tool for improving the productive attributes of sheep populations. Special emphasis has been done in some sheep extensive farms in the region of Magallanes, in the Chilean Patagonia, where in addition to increasing the production of fine wool, it has been sought to develop a smaller sheep with higher meat value in Merino-type breeds.

The result of this directional selection over time could have led to the emergence and development of a type of animal with high grazing skills under the harsh conditions of the Magellanic Patagonia, with ultrafine wool and a relatively different body compared to Merino. In this paper, we analyze the degree of differentiation and the morphostructural variability achieved by the type of animal resulting after this sustained directional selection, and the implications on the emergence of a new sheep breed.

\section{MATERIAL AND METHOD}

The evaluations were carried out at Estancia Tres Hermanos, Tierra del Fuego, Chile, in summer 2012. The study population was obtained from a core of 3000 sheep which descent from Australian Merino breed and have been submitted to directional selection since 1987. The first four years of the selective process (1987-1990), national Merino rams were used for breeding. Afterwards, and for 21 years, ewes were inseminated with frozen semen from Merino Multipurpose imported from Australia. The selection scheme was focused on finding an animal of greater body size and length, with a fineness of fleece around 22 or 23 microns, open face, soft nasal profile, white hooves and high prolificacy.

The sample was randomly taken from the 3000 head flock mentioned above, calculating the sample size through the formula used in other similar studies (Latorre et al., 2011; De la Barra et al., 2013).

\footnotetext{
* Instituto de Investigaciones Agropecuarias (INIA), Centro Experimental Butalcura, Chiloé, Chile.

** Instituto de Investigaciones Agropecuarias (INIA), Centro Regional Kampenaike, Punta Arenas, Chile.
} 


$$
\text { Sample size }=1 /\left(\frac{1}{n_{1}}+\frac{1}{P o p}\right)
$$

Where:

$$
\begin{gathered}
\text { Pop }=\text { Population size } \\
n_{1}=\frac{4 p q}{L^{2}}
\end{gathered}
$$

$\mathrm{p}=$ Proportion of individuals in the population expected to be representative of the study population.

$\mathrm{q}=1-\mathrm{p}$

$\mathrm{L}=$ Allowed error

It was estimated that $85 \%$ of individuals in the population were representative of the new animal format, with an allowed error of $5 \%$.

Twenty-five rams and 200 adult sheep were measured. Measures were compared to identical measurements taken on 2011 on Australian Merino (100 ewes and 25 rams) and Marin Magellan Meat Merino (100 ewes and 25 rams). All the animals used in this study were healthy adults.

Thirteen body measurements were taken (Riva et al., 2004; Calderón et al., 2009, Herrera \& Luque, 2009; Bravo \& Sepúlveda, 2010; Latorre et al.). The body measurements used were face length (LCa), skull length (LCr), skull width (ACr), head width (AC), chest width (AP), chest circumference (PT), rump width (AG), rump length (LG), dorso-sternal diameter (DD), bicostal diameter (DB), longitudinal diameter (DL), elevation of the cross (ALC) and elevation of the rump (ALGr).

The structural morphology differentiation compared to other Merino-like breeds and the sexual dimorphism were evaluated through student $t$ test, comparing the averages of the body measurements. The intrapopulation homogeneity was assessed using the coefficients of percentage variation of the average of the body measurements. Data processing was carried out using a Microsoft Excel spreadsheet by means of the XLSTAT 2006 program.

\section{RESULTS AND DISCUSSION}

At first place results regarding the morphostructural differentiation of the study population relative to Merino- type breed populations are presented. Secondly, the homogeneity within the study population is studied.

Morphostructure provides information susceptible to be used on ethnological characterization of an animal population, and allows a judgment of the productive potential based on the implicit mechanical relationships within the morphologic structure (Zaitoun et al., 2005; Traoré et al., 2008; Yakubu et al., 2010a). Therefore, morphology expresses a strong relationship with productive potential, since it contains the structure which supports the biological functionality of the animal (Alpak et al., 2009). If this relationship is not considered, it would imply that appropriate productive life adaptation models would not be right (Bravo \& Sepúlveda; Yakubu et al., 2010b).

\section{Interpopulation differentiation}

Table I shows the morphostructural differences in adult males and females in the study population compared to Australian Merino. There are significant differences in almost all body measurements, with the exception of ALGr in females. Therefore, we can say that the population evaluated presents a different animal format, both for females and for males, compared to Australian Merino breed.

It is noted that both females and males of the study population presented a slightly longer face, in the context of a reduced head, than Australian Merino does. Regarding this, several authors have pointed out that facial and head differences are very important from an ethnological point of view in breed identification (Sierra Alfranca, 2001; Delgado et al., 2001; Herrera \& Luque). These findings, plus the ethnological differences, are the basic concepts on the foundation of a breed (Sierra Alfranca).

Both males and females are smaller animals than Australian Merino in most of the body measurements related to meat value (rump length, chest width, chest circumference, dorso-sternal diameter and bicostal diameter). According to several authors, these morphostructural changes are related to changes in the productive performance of the animal format; therefore, in the sustained selection process, not only changes in ethnological traits are involved, but also productive traits (Salako, 2006; Yakubu, 2010; Yakubu et al., 2010a).

Table II shows the morphostructural differences between the study population and Marin Magellan Meat Merino ewes. Significant differences were found in most body measurements, with the only similarities found in dorso-sternal diameter, bicostal diameter and longitudinal diameter. However, it can be pointed out that even though 
Table I. Morphological and structural differences between males and females in the study population and Australian Merino breed.

\begin{tabular}{|c|c|c|c|c|c|c|}
\hline \multirow[b]{2}{*}{$\begin{array}{l}\text { Biometric } \\
\text { Variable }\end{array}$} & \multicolumn{3}{|c|}{ Females } & \multicolumn{3}{|c|}{ Males } \\
\hline & $\begin{array}{c}\text { Study } \\
\text { population (1) }\end{array}$ & $\begin{array}{l}\text { Australian } \\
\text { Merino (2) }\end{array}$ & $\begin{array}{l}\text { Difference } \\
(1-2)\end{array}$ & $\begin{array}{c}\text { Study } \\
\text { population (3) }\end{array}$ & $\begin{array}{l}\text { Australian } \\
\text { Merino (4) }\end{array}$ & $\begin{array}{c}\text { Difference } \\
(3-4)\end{array}$ \\
\hline LCa & 18.43 & 18.17 & $0.26 * * *$ & 20.54 & 23.67 & $-3.13 * * *$ \\
\hline $\mathbf{L C r}$ & 9.70 & 10.88 & $-1.18 * * *$ & 13.18 & 10.64 & $2.54 * * *$ \\
\hline $\mathrm{ACr}$ & 9.23 & 10.67 & $-1.44 * * *$ & 13.91 & 12.82 & $1.09 * * *$ \\
\hline $\mathrm{AC}$ & 12.96 & 13.48 & $-0.52 * * *$ & 15.17 & 14.14 & $1.03 * * *$ \\
\hline $\mathbf{A P}$ & 20.65 & 22.48 & $-1.83 * * *$ & 25.25 & 26.12 & $-0.87 *$ \\
\hline PT & 94.85 & 100.26 & $-5.41 * *$ & 103.60 & 109.20 & $-5.6 * * *$ \\
\hline AG & 12.70 & 20.18 & $-7.48 * * *$ & 18.58 & 22.72 & $-4.14 * * *$ \\
\hline LG & 15.14 & 17.49 & $-2.35 * * *$ & 22.86 & 20.39 & $2.47 * * *$ \\
\hline DD & 30.45 & 33.86 & $-3.41 * * *$ & 32.42 & 37.12 & $-4.7 * * *$ \\
\hline DB & 22.26 & 25.34 & $-3.08 * * *$ & 23.83 & 26.93 & $-3.1 * * *$ \\
\hline DL & 72.08 & 74.85 & $-2.77 * *$ & 77.86 & 81.08 & $-3.22 * * *$ \\
\hline ALC & 66.74 & 67.87 & $-1.13^{*}$ & 72.85 & 80.06 & $-7.21 * * *$ \\
\hline ALGr & 67.81 & 68.45 & $-0.64 \mathrm{Ns}$ & 75.30 & 79.28 & $-3.98 * * *$ \\
\hline
\end{tabular}

*** $\mathrm{P}<0.001, * * \mathrm{p}<0.01, * \mathrm{p}<0.05, \mathrm{~ns}=$ not significant.

Table II. Morphological and structural differences between males and females in the study population and Marin Magellan Meat Merino.

\begin{tabular}{lcccccc}
\hline & \multicolumn{3}{c}{ Females } & \multicolumn{2}{c}{ Males } \\
\cline { 2 - 7 } Biometric & $\begin{array}{c}\text { Study } \\
\text { Variable }\end{array}$ & $\begin{array}{c}\text { Marin Magellan } \\
\text { population (1) }\end{array}$ & $\begin{array}{c}\text { Deat Merino (2) } \\
(\mathbf{1 - 2})\end{array}$ & $\begin{array}{c}\text { Study } \\
\text { population (3) }\end{array}$ & $\begin{array}{c}\text { Marin Magellan } \\
\text { Meat Merino (4) }\end{array}$ & $\begin{array}{c}\text { Difference } \\
(\mathbf{3 - 4})\end{array}$ \\
\hline LCa & 18.43 & 18.65 & $-0.22^{* * *}$ & 20.54 & 20.73 & $-0.19^{* * *}$ \\
LCr & 8.70 & 7.27 & $1.43^{* * *}$ & 13.18 & 9.33 & $3.85^{* * *}$ \\
ACr & 9.23 & 7.36 & $1.87^{* * *}$ & 13.91 & 9.46 & $4.45^{* * *}$ \\
AC & 12.96 & 12.16 & $0.8^{* * *}$ & 15.17 & 13.32 & $1.85^{* * *}$ \\
AP & 20.65 & 22.23 & $-1.58^{* * *}$ & 25.25 & 27.21 & $-1.96^{* * * *}$ \\
PT & 94.85 & 88.13 & $6.72^{* * *}$ & 103.60 & 108.00 & $-4.4^{* *}$ \\
AG & 12.70 & 12.00 & $0.7 * * *$ & 18.58 & 15.95 & $2.63^{* * *}$ \\
LG & 15.14 & 13.14 & $2.0^{* * *}$ & 22.86 & 17.39 & $5.47^{* * *}$ \\
DD & 30.45 & 30.98 & $-0.53 \mathrm{~ns}$ & 32.42 & 38.05 & $-5.63^{* * *}$ \\
DB & 22.26 & 22.70 & $-0.44 \mathrm{~ns}$ & 23.83 & 28.57 & $-4.74^{* * *}$ \\
DL & 72.08 & 71.04 & $-1.04 \mathrm{~ns}$ & 77.86 & 90.82 & $-12.96^{* * *}$ \\
ALC & 66.74 & 69.26 & $-2.52^{* * *}$ & 72.85 & 81.40 & $-8.55^{* * *}$ \\
ALGr & 67.81 & 70.61 & $-2.8 * * *$ & 75.30 & 81.33 & $-6.03^{* * * *}$ \\
\hline
\end{tabular}

*** $\mathrm{P}<0.001, * * \mathrm{p}<0.01, * \mathrm{p}<0.05, \mathrm{~ns}=$ not significant.

there are similarities in some body dimensions, the study population corresponds to a different sheep format. Here, as the case of comparison with Australian Merino breed, the study population has a slightly more reduced face in the context of a larger head volume compared to Marin Magellan Meat Merino, difference that, as already mentioned, is pointed out by several authors as a main feature in racial identification (Sierra Alfranca; Delgado et al.; Herrera \& Luque). In both males and females of the study population, it can be apreciated a wider and longer rump compared to Marin Magellan Meat Merino. Ewes in the study population have a higher thoracic amplitude than Marin Magellan Meat Merino, while this area is smaller in rams.

\section{Intrapopulation homogeneity and sexual dimorphism}

Whether a population can be clearly distinguished, it is necessary to determine whether differentiating characters are modal, i.e., if within that population there is an animal format with low variability. This could allow us to identify the population as a group of individuals with some similarity between them, or at least with the same variation coefficient as other already established sheep breeds. In this respect, Herrera \& Luque suggested direct comparison of the percent variation coefficients as a real morphostructural homogeneity test. Several authors have successfully made evaluations on different sheep breeds using this criterion: Espinace (2009) 
Table III. Intrapopulation morphostructural variability and sexual dimorphism of the study population.

\begin{tabular}{lccccc}
\hline $\begin{array}{l}\text { Biometric } \\
\text { Variable }\end{array}$ & $\begin{array}{c}\text { Media males } \\
(\mathbf{A})(\mathbf{c m})\end{array}$ & $\begin{array}{c}\text { Media females } \\
(\mathbf{B})(\mathbf{c m})\end{array}$ & $\begin{array}{c}\text { Difference } \\
(\mathbf{A}-\mathbf{b})(\mathbf{c m})\end{array}$ & $\begin{array}{c}\text { Variation coefficien t } \\
\text { males }(\boldsymbol{\%})\end{array}$ & $\begin{array}{c}\text { Variation coefficient } \\
\text { females }(\boldsymbol{\%})\end{array}$ \\
\hline LCa & 20.54 & 18.43 & $2.11^{* *}$ & 6.27 & 4.37 \\
LCr & 13.18 & 8.70 & $4.48^{* * *}$ & 8.37 & 4.72 \\
ACr & 13.91 & 9.23 & $4.68^{* * *}$ & 6.86 & 5.02 \\
AC & 15.17 & 12.96 & $2.21^{* *}$ & 4.72 & 3.86 \\
AP & 25.25 & 20.65 & $4.60^{* *}$ & 8.32 & 7.14 \\
PT & 103.60 & 94.85 & $8.75^{* *}$ & 4.38 & 10.56 \\
AG & 18.58 & 12.70 & $5.88^{* * *}$ & 6.78 & 5.95 \\
LG & 22.86 & 15.14 & $7.72^{* * *}$ & 7.54 & 6.73 \\
DD & 32.42 & 30.45 & $1.97 \mathrm{~ns}$ & 6.25 & 6.93 \\
DB & 23.83 & 22.26 & $1.57 \mathrm{~ns}$ & 4.39 & 3.62 \\
DL & 77.86 & 72.08 & $5.78^{* * *}$ & 3.99 & 3.91 \\
ALC & 72.85 & 66.74 & $6.11^{* * *}$ & 3.81 & 3.88 \\
ALGr & 75.30 & 67.81 & $7.49^{* * *}$ & 6.27 & 4.37 \\
\hline
\end{tabular}

*** $\mathrm{P}<0.001, * * \mathrm{p}<0.01, * \mathrm{p}<0.05, \mathrm{~ns}=$ not significant

in Suffolk Down; Calderón et al. in Suffolk Down, Romney Marsh and Chilota; Bravo \& Sepúlveda, in Araucana; and De la Barra et al. (2011) in Chilota.

Coefficients of variation of morphostructural measures in the study population are presented in Table III. It is appreciated that none of them show values higher than $10 \%$. These values are similar, and in several cases minor, to those reported by Espinace and Calderón et al. for adult females in Suffolk Down breed. Calderón et al., also reported similar values in Romney Marsh females, and Latorre et al. in Magellan Meat Merino Marin adult females. De la Barra et al. (2011) and Latorre et al. found similar coefficients of variation, and higher than those reported for the population under study in the case of racial studies of males and females from Marin Magellan Meat Merino and Chilota breeds. In this regard, Sierra Alfranca pointed out that these findings, plus the ethnological differences, are the basic concepts on the foundation of a breed, so it is possible to state that the morphostructural variability of the study population is similar, and in many cases lower, to that found in recognized sheep breeds. Therefore, the study population behaves as a group with defined racial characteristics.

Finally, it is interesting to point out the marked sexual dimorphism observed within the study population, where almost all morphostructural dimensions are significantly higher in males. This phenomenon is a consequence of the selection process, accentuated by the greater selection pressure applied to the rams. In this regard, De la Barra et al. (2008) pointed out that this situation is common in selected sheep populations. These authors showed that sexual dimorphism was not observed in the initial studies of an unselected population of Chilota sheep in the Chiloé Archipelago, but it appeared when the population was constituted as a breed and directional selection processes were applied by breeders.

In conclusión, it can be said that the sustained directional selection over time has generated the differentiation of the morphostructural format in the subject population compared to the main Merino-type breeds existing in Chilean Patagonia (Australian Merino and Marin Magellan Meat Merino). In this regard, it may be pointed out that the studied population shows a similar morphostructural variability, and in many cases lower, than those found in some recognized sheep breeds in Chile, so it is possible to state that it behaves as a distinct animal group with breed characteristics.

\section{ACKNOWLEDGEMENTS}

The authors wish to acknowledge Mr. Ivo Robertson and his family, for their facilities on the process of evaluation and for their long and dedicated work of selection.

DE LA BARRA, R.; LATORRE, E.;MARTÍNEZ, M. E. \& CALDERÓN, C. Diferenciación y variabilidad morfoestructural de ovinos de raza Merino sometidos a selección direccional sostenida. Int. J. Morphol., 32(3):1069-1073, 2014.

RESUMEN: En el presente trabajo se analiza el grado de diferenciación y variabilidad morfoestructural alcanzado por el tipo de animal resultante de una selección direccional sostenida y sus implicancias en la emergencia de un nuevo grupo racial ovino. Se midieron 25 machos y 200 ovejas adultas. Se tomaron 13 medidas corporales, evaluando la diferenciación de la morfología estructural y el dimorfismo sexual. Estas mediciones se compararon con 
las realizadas en animales de raza Merino Australiano y Marin Magellan Meat Merino. La homogeneidad intrapoblacional se evaluó a través de los coeficientes de variación porcentual de las medias de las medidas corporales. Se concluye que la selección direccional realizada de forma sostenida ha generado una diferenciación del formato morfoestructural al comparar a la población sujeta a selección con las principales raza de tipo Merino existentes en la Patagonia Chilena. La población evaluada evidencia una variabilidad morfoestructural similar, y en muchos casos menor a la encontrada en razas ovinas reconocidas como tales en Chile, con lo cual es posible señalar que se comporta como un grupo animal distinguible con caracteres de raza.

PALABRAS CLAVE: Reproducción; Genética; Morfología.

\section{REFERENCES}

Alpak, H.; Onar, V. \& Mutus, R. The relationship between morphometric and long bone measurements of the Morkaraman sheep. Turk. J. Vet. Anim. Sci., 33(3):199-207, 2009.

Bravo, S. \& Sepúlveda, N. Zoometric Indices in Araucanas Creole Ewes. Int. J. Morphol., 28(2):489-95, 2010.

Calderón, C.; De la Barra, R.; Martínez, M. E. \& Gonzalo, C. Variabilidad fenotípica morfoestructural de las razas ovinas predominantes en Chiloé. Pucón, VII Simposio de recursos genéticos para América latina y el Caribe (SIRGEALC), 2009. pp.157-8.

De la Barra, R.; Corvalán, P.; Martínez, M. E.; Gonzalo, C. \& San Primitivo, F. Dimorfismo sexual en el ovino Criollo Chilote. Valdivia, VIII Congreso de la Federación Iberoamericana de razas Criollas y Autóctonas, 2008.

De la Barra, R.; Carvajal, A.; Uribe, H.; Martínez, M. E.; Gonzalo, C.; Arranz, J. \& San Primitivo, F. El ovino criollo Chilote y su potencial productivo. Anim. Genet. Resour., 48:93-9, 2011.

De la Barra, R.; Martínez, M.E.; Calderón, C. \& Latorre, E. Intergenerational morphostructural stability and harmony of marin magellan meat merino ewes. Int. J. Morphol., 31(4):1455-8, 2013.

Delgado, J. V.; Barba, C.; Camacho, M. E.; Sereno, F.; Martínez, A. \& Vega-Pla, J. L. Caracterización de los animales domésticos en España. AGRI-FAO, 29:7-18, 2001.

Espinace, B. Evaluación etnológica de la raza Suffolk Down en Chile. Tesis de grado para Médico Veterinario. Puerto Montt, Universidad Santo Tomás, 2009. pp.85.

Herrera, M. \& Luque, M. Morfoestructura y sistemas para el futuro en la valoración morfológica. En: Sañudo, A. C. (Ed.). Valoración morfológica de los animales domésticos. Madrid,
Ministerio de Medio Ambiente y Medio Rural y Marino, 2009.

Latorre, E.; Uribe, H.; Martínez, M. E.; Calderón, C. \& De la Barra, R. Morphology differentiation and structural functionality of ewes due to incomplete crossbreeding. Int. J. Morphol., 29(3):954-9, 2011.

Riva, J.; Rizzi, R.; Marelli, S. \& Cavalchini, L. G. Body measurements in Bergamasca sheep. Small Rumin. Res., 55(13):221-7, 2004.

Salako, A. E. Application of morphological indices in the assessment of type and function in sheep. Int. J. Morphol., 24(1):13-8, 2006.

Sierra Alfranca, I. The breed concept: evolution and reality. Arch. Zootec., 50:547-64, 2001.

Traoré, A.; Tamboura, H. H.; Kaboré, A.; Royo, L. J.; Fernández, I.; Álvarez, I.; Sangaré, M.; Bouchel, D.; Poivey, J. P.; Francois, D.; Toguyeni, A.; Sawadogo, L. \& Goyache, F. Multivariate characterization of morphological traits in Burkina Faso sheep. Small Rumin. Res., 80(1-3):62-7, 2008.

Yakubu, A. Path coefficient and path analysis of body weight and biometric traits in Yankasa lambs. Slovak. J. Anim. Sci., 43(1):17-25, 2010.

Yakubu, A.; Salako, A. E.; Imumorin, I. G.; Ige, A. O. \& Akinyemi, M. O. Discriminant analysis of morphometric differentiation in the West African Dwarf and Red Sokoto goats. S. Afr. J. Anim. Sci., 40:381-7, 2010a.

Yakubu A.; Salako, A. E. \& Imumorin, I. G. Multivariate analysis of spatial patterns of morphological traits in West African Dwarf goats in three agro-ecological zones of Nigeria. J. Appl. Anim. Res., 38:257-60, 2010b.

Zaitoun, I. S.; Tabbaa, M. J. \& Bdour, S. Differentiation of native goat breeds of Jordan on the basis of morphostructural characteristics. Small Rumin. Res., 56(1-3):173-82, 2005.

Correspondence to:

María Eugenia Martínez

Instituto de Investigaciones Agropecuarias (INIA)

Centro Experimental Butalcura

Chiloé

CHILE

Email: eugemartinez.inia@gmail.com

Received: 05-03-2014

Accepted: 31-07-2014 